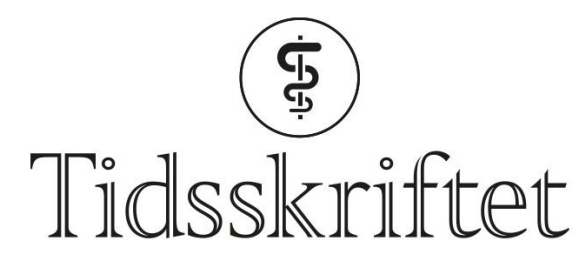

DEN NORSKE LEGEFORENING

\title{
Historien i kroppen
}

ANMELDELSER

KETIL SLAGSTAD

Tidsskriftet

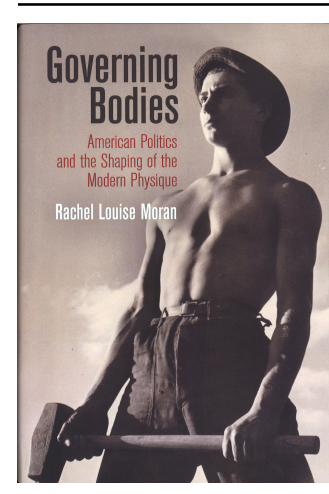

Rachel Louise Moran

Governing bodies

American politics and the shaping of the modern physique. $216 \mathrm{~s}$, ill. Philadelphia, PA: Penn Press, 2018. Pris GBP 38

ISBN 978-0-8122-5019-0

Som nyutdannet lege var jeg vant til å tenke på kroppen som en velavgrenset enhet: Hver og en av oss har en kropp som vi beveger oss gjennom verden med, som vi kan gjøre dumme eller kloke valg for, som kan være frisk eller syk, og som legen kan intervenere i gjennom råd, piller og kirurgi. Men kroppen er også en historisk og politisk størrelse: Ikke bare har kroppsidealer og kroppsforståelser skiftet gjennom tidene, men kroppen selv har blitt endret som resultat av statlig politikk. En ny bok utvider forståelsen vår av hvordan.

I Governing Bodies: American Politics and the Shaping of the Modern Physique analyserer historikeren Rachel Louise Moran hvordan den amerikanske kroppen har vært gjenstand for statlige intervensjoner fra før første verdenskrig til slutten av 1970-årene. I stor grad har politikken lent seg mot vitenskap og statistikk og tatt i bruk virkemidler som veiing, måling, telling og kvantifisering for å legitimere statlig bruk av makt. Særlig tydelig fremkommer det hvor subtil den amerikanske statens maktbruk har vært.

Ved bruk av arkivmateriale og trykte kilder tegner Moran seks historiske kasus. Hun starter med tiden før, under og etter første verdenskrig - en tid med økende nasjonal angst for at befolkningen var i for dårlig fysisk form for krig. Mødre ble oppfordret til å veie og måle sine barn for å lage staute soldater for nasjonen. Under depresjonstiden ble arbeidsledige menn innlemmet i nasjonale skogplantingsprogram for å forhindre lediggang. Primært 
hvite, arbeidsføre amerikanere fikk adgang og frontet programmet utad: Gjennom hardt arbeid, gymnastikk og sunn kost ble idealet om den hvite, heteroseksuelle,

funksjonsdyktige, muskuløse mannskroppen formet. Den annen verdenskrig ga mulighet for en mer inngripende statlig politikk. Sesjonsutvelgelsen forsterket maskulinitetsidealet.

Kvinners inntog på arbeidsmarkedet i etterkrigstiden gjorde at staten i økende grad så behov også for å rette tiltakene mot kvinnekroppen for å sikre en arbeidsfør befolkning. Utover i 1960- og 70-årene ble oppmerksomheten rettet mot sult og avmagrede svarte barn i sørstatene og den tykke (ofte svarte) moren som angivelig utnyttet velferdssystemet.

Liberale og konservative politikere (inkludert sørstatsdemokrater) kranglet på hver sin side om sult fantes eller ikke og hvorvidt statens politikk hadde feilet. I økende grad dannet det seg et bilde av den tykke mor som uansvarlig som verken passet på barnets eller egen kropp. Dermed viser Moran noe av den historiske bakgrunnen for den utbredte og stigmatiserende misoppfatningen om at vekt er et individuelt ansvar eller at personer med fedme mangler viljestyrke.

Jeg skulle gjerne sett at boken trakk linjene helt frem til i dag. Den er godt skrevet og kan anbefales for alle med interesse for amerikansk historie og for dem som er interessert $\mathrm{i}$ å forstå hvordan historien er innskrevet i kroppene våre.

Publisert: 10. desember 2018. Tidsskr Nor Legeforen. DOI: 10.4045/tidsskr.18.0777

(C) Tidsskrift for Den norske legeforening 2020. Lastet ned fra tidsskriftet.no 